\title{
Raising the Bar -
}

\section{Transformative Ethics and the Example of Christ}

\author{
Cam Caldwell ${ }^{1} \&$ C. Stewart Holloway ${ }^{2}$ \\ ${ }^{1}$ Alexandria, Louisiana, USA \\ ${ }^{2}$ First Baptist Church, Pineville, Louisiana, USA \\ Correspondence: Cam Caldwell, Alexandria, Louisiana, USA
}

Received: September 23, 2017

Accepted: October 30, 2017

Online Published: November 2, 2017

doi:10.5430/bmr.v6n4p54

URL: https://doi.org/10.5430/bmr.v6n4p54

\begin{abstract}
Transformative Ethics, a newly established ethical model that incorporates twelve other ethical perspectives, is briefly described in this paper and the life of Jesus Christ is used as a model for that perspective. The paper summarizes the fundamental ideas of each of the twelve widely-accepted ethical perspectives and gives examples that demonstrate behaviors that have application in the individual lives of leaders and others who seek to be trusted by their associates.
\end{abstract}

Keywords: Transformative Ethics, Ethical Leadership, Life of Christ, Leading by Example, Trust, Trustworthiness

Objective: The purpose of this paper is to briefly explain Transformative Ethics and to identify how the life of Jesus Christ reflects his example as one who demonstrates that ethical model.

Method: This is a conceptual paper that examines and integrates the ethics literature with concepts related to the life of Jesus Christ, as described in the New Testament, to demonstrate the ultimate importance of ethical behaviors in earning the trust of others.

Results: The paper identifies twelve fundamental qualities of Transformative Ethics, provides four insights about that ethical model's practical implications, and challenges individuals to adopt that ethical model in their own lives.

Conclusion: Those who seek to lead must follow an ethically virtuous model that addresses the varying ethical perspectives of others and Transformative Ethics provides an ethical standard with profoundly practical applications.

In the hurly-burly of everyday living, leaders have struggled for decades about daily choices and the moral and ethical standards required of their decisions, their relationships, and their daunting responsibilities (Sims, 1992, Ware, 2010). Frequently, leaders' actions are spontaneous, contextually complex, and fraught with seemingly conflicting obligations to multiple stakeholders (Schwartz, 2016). Leaders are regularly faced with ethical dilemmas (Badaracco, 2016) - often struggling with the inability to foretell precisely the consequences of alternative choices and the impacts of decisions on those who are affected (Hosmer, 2010). Yet ethical decision-making and leadership are much like the two sides of the same coin (Burns, 2010) and, despite the uncertainties, leaders are expected to be honorable, fair, and consistent if they expect to be trusted and followed (Kouzes \& Posner, 2016).

The purpose of this paper is to use the example of Jesus Christ, considered by many to be "the one perfect leader," as an exemplar of Transformative Ethics (TE). TE is a new model of ethical conduct that integrates twelve other widely-known ethical perspectives (Caldwell \& Anderson, 2017). We present this TE model within the context of Christ's example to identify its practical nature and its application for individuals who aspire to integrate their religious and secular lives to achieve personal congruence, alignment, and moral consistency. We begin by briefly defining TE and identifying the twelve ethical perspectives which it combines. Citing examples from the life of Christ, we suggest that Christ's actions meshed with all twelve of those ethical perspectives. We conclude the paper by identifying four insights that leaders and other individuals can incorporate as they strive to raise the bar of their own ethical standards and personal conduct. 


\section{Defining Transformative Ethics}

TE was defined by Caldwell and Anderson $(2017$, p. 2) as "the highest standard of ethical and moral performance" which complies with the conduct required of twelve frequently-cited and highly-regarded ethical perspectives. Cameron (2003) and Whetten (1996) had previously identified the importance of a "virtuous" commitment to moral behavior which sought to pursue outcomes which benefited all stakeholders, optimized the creation of value, and adopted a long-term focus rather than the pursuit of short-term results. That virtuous position, they suggested, 1) required conduct which was more than simply "moral" but sought the highest and best benefit for others; and 2) reflected a commitment to honor truth, respect the rights of individuals, and comply with correct principles. Diagram 1 differentiates between the virtuous moral position and other options on the Virtuous Continuum (Caldwell, Hasan, \& Smith, 2015).

Diagram 1. The Virtuous Continuum

Virtuous

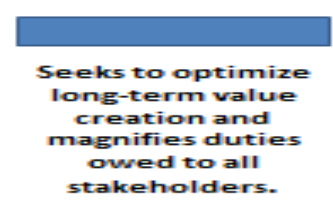

Moral

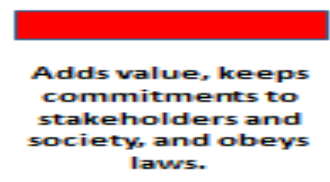

Amoral

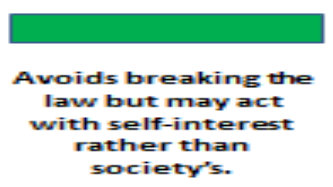

Immoral

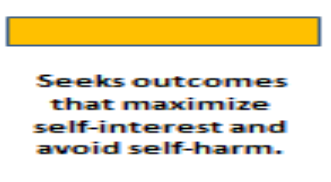

This Virtuous Continuum distinguishes between four levels of moral behavior and builds upon the research of well-regarded scholars about duties owed to stakeholders in honoring leadership obligations (cf. Carroll \& Buchholtz 2014). Although the moral position adds value and keeps commitments, the virtuous position is morally superior because it optimizes value creation and magnifies duties owed in serving others. The amoral position may not be illegal but adopts a personal self-interest that may often be detrimental to others, and the immoral position is ethically inferior and ultimately self-defeating long-term (Carroll \& Buchholtz, 2014).

The twelve ethical perspectives that make up TE are commonly known and frequently cited by other scholars (Hosmer, 1995; Myhre, 2013). Table 1, provided below, identifies the twelve ethical perspectives included by Caldwell and Anderson (2017) in their TE model. This table also briefly summarizes the fundamental idea for each of the twelve perspectives and the contribution of each ethic to virtuous conduct. 
Table 1. Twelve Contributing Ethical Perspectives to Virtuous Conduct

\begin{tabular}{|c|c|c|}
\hline $\begin{array}{l}\text { Ethical } \\
\text { Perspective }\end{array}$ & Fundamental Idea & Contribution to Virtuous Conduct \\
\hline $\begin{array}{l}\text { Ethic of } \\
\text { Self-Interest }\end{array}$ & $\begin{array}{l}\text { "Pursue outcomes which have the } \\
\text { greatest positive benefit for oneself and } \\
\text { one's organization without infringing } \\
\text { upon the rights of others." }\end{array}$ & $\begin{array}{l}\text { Acknowledges that value creation is } \\
\text { important and self-interest is beneficial, but } \\
\text { that others have rights that must also be } \\
\text { honored. }\end{array}$ \\
\hline Virtue Ethics & $\begin{array}{l}\text { "Constantly pursue excellence, make } \\
\text { that pursuit a habit, and treat others with } \\
\text { integrity." }\end{array}$ & $\begin{array}{l}\text { Confirms that to be honorable and to } \\
\text { develop habits of excellence are requisites } \\
\text { as personal standards. }\end{array}$ \\
\hline $\begin{array}{l}\text { Ethic of Religious } \\
\text { Injunction }\end{array}$ & $\begin{array}{l}\text { "Always treat others with dignity, } \\
\text { respect, and kindness - as valued 'Yous' } \\
\text { and never as anonymous 'Its."” }\end{array}$ & $\begin{array}{l}\text { Requires that others be treated with } \\
\text { kindness, compassion, and empathy at all } \\
\text { times. }\end{array}$ \\
\hline $\begin{array}{l}\text { Ethic of } \\
\text { Government } \\
\text { Regulation }\end{array}$ & $\begin{array}{l}\text { "Live by both the letter and the spirit of } \\
\text { the law in honoring duties owed to } \\
\text { others, but remember that the law by } \\
\text { itself is a minimal moral standard." }\end{array}$ & $\begin{array}{l}\text { Confirms that the purpose of rules must } \\
\text { always be taken into account and that the } \\
\text { intent of those rules is as critical as or more } \\
\text { important than the letter. }\end{array}$ \\
\hline Utilitarian Ethics & $\begin{array}{l}\text { "No actions should be engaged in which } \\
\text { do not result in the greatest good for that } \\
\text { community of which you are a part." }\end{array}$ & $\begin{array}{l}\text { Affirms that this greatest good is both } \\
\text { outcome-oriented and rights-oriented in } \\
\text { creating value - with an obligation to } \\
\text { minimize any possible harm. }\end{array}$ \\
\hline $\begin{array}{l}\text { Ethic of Universal } \\
\text { Rules }\end{array}$ & $\begin{array}{l}\text { "Act according to universal principles } \\
\text { and rules which you would have others } \\
\text { apply if they were in your similar } \\
\text { situation and your positions were } \\
\text { reversed." }\end{array}$ & $\begin{array}{l}\text { Treats others as they wish to be treated and } \\
\text { complies with universally-understood } \\
\text { principles that benefit mankind. }\end{array}$ \\
\hline $\begin{array}{l}\text { Ethic of Universal } \\
\text { Rights }\end{array}$ & $\begin{array}{l}\text { "No one, including governments, may } \\
\text { take action that infringes upon the } \\
\text { legitimate rights of any other } \\
\text { individual." }\end{array}$ & $\begin{array}{l}\text { Honors basic human rights and ensures } \\
\text { that those rights may not be infringed upon } \\
\text { - even under color of claim for a public } \\
\text { benefit. }\end{array}$ \\
\hline $\begin{array}{l}\text { Ethic of } \\
\text { Economic } \\
\text { Efficiency }\end{array}$ & $\begin{array}{l}\text { "Achieving an efficient use of resources } \\
\text { to create value for society is a virtuous } \\
\text { goal." }\end{array}$ & $\begin{array}{l}\text { Conserves and efficiently uses scarce } \\
\text { resources and acknowledges that efficient } \\
\text { and effective value creation benefits society. }\end{array}$ \\
\hline $\begin{array}{l}\text { Ethic of } \\
\text { Distributive } \\
\text { Justice }\end{array}$ & $\begin{array}{l}\text { "Act only in ways that acknowledge the } \\
\text { rights, liberty, and equality of all and } \\
\text { take no actions that harm the least } \\
\text { among us." }\end{array}$ & $\begin{array}{l}\text { Recognizes that, though justice is a } \\
\text { multi-faceted construct, no actions should } \\
\text { be taken that harm those who are } \\
\text { disadvantaged in society. }\end{array}$ \\
\hline $\begin{array}{l}\text { Ethic of } \\
\text { Contributing } \\
\text { Liberty }\end{array}$ & $\begin{array}{l}\text { "Take no actions which impede the } \\
\text { self-development or self-fulfillment of } \\
\text { others." }\end{array}$ & $\begin{array}{l}\text { Promotes the liberty which allows all } \\
\text { individuals to pursue self-development and } \\
\text { self-fulfillment and acknowledges that } \\
\text { society benefits thereby. }\end{array}$ \\
\hline $\begin{array}{l}\text { Ethic of } \\
\text { Self-Actualization }\end{array}$ & $\begin{array}{l}\text { "Seek to discover your innate greatness } \\
\text { and fulfill that potential to create a better } \\
\text { world." }\end{array}$ & $\begin{array}{l}\text { Emphasizes the innate talents, gifts, and } \\
\text { highest potential of individuals and the } \\
\text { responsibility to use those talents } \\
\text { productively to make a better world. }\end{array}$ \\
\hline Ethic of Care & $\begin{array}{l}\text { "Respect others as valued individuals, } \\
\text { share concern for their welfare, and } \\
\text { honor the responsibility to treat each } \\
\text { person with empathy and compassion." }\end{array}$ & $\begin{array}{l}\text { Affirms the responsibility to care for } \\
\text { others' best interests and to treat them with } \\
\text { love and with demonstrated concern for } \\
\text { their welfare and wholeness. }\end{array}$ \\
\hline
\end{tabular}


Interpersonal relationships and the obligations owed to others by leaders are often acknowledged to be ethically dependent concepts (Burns, 2010; Solomon, 1993). Table 1's brief summary of TE clarifies the importance of each ethical perspective as it relates to positive outcomes. In each person's quest to become the best version of oneself (Covey, 2004) and to help create a better world (Friedman, 2009), TE's commitment to honorable actions and virtuous conduct is aligned with those worthy purposes.

As a standard for personal behavior, TE rises to the level of ethical stewardship (Caldwell, Hayes, Karri, \& Bernal, 2008) and honors the steward's obligation to optimize virtuous outcomes (Hernandez, 2008 \& 2012). This stewardship commitment is a morally-focused responsibility that pursues the best interests of society; benefits all stakeholders; and is fair, just, and focused on enhancing the welfare of all parties (Baker, 2017). In writing about the steward's responsibilities, Block (2013) explained that the steward chooses service over self-interest.

DePree (2004, Ch. 1) explained that a "covenantal" obligation encompassed the moral responsibility of those who take on the mantle of leadership. Leaders are expected to create the optimal benefit for organizations by enabling and empowering others to achieve the best within themselves (Burns, 2010). In his insightful book, The Road Less Traveled, M. Scott Peck (2003) defined love as treating oneself and/or others with a commitment to their welfare, growth, and wholeness. Virtuous conduct and ethical stewardship demonstrate that same commitment and honor the leader's responsibility to self, to others, and to society (Caldwell, et al., 2008). Accordingly, it seems reasonable to conclude that TE becomes a leader's expression of love to those whom (s)he serves.

\section{Applying the Model to Christ}

In the following sections we briefly describe the twelve ethical perspectives which make up TE and apply those perspectives to specific examples from the life of Christ, as recorded in the New Testament. Each of these twelve sections demonstrates actions that confirm that Christ's interpersonal relationships were consistently aligned with the respective ethical perspectives.

\section{Ethic of Self-Interest}

The Ethic of Self-Interest (ESI) seeks outcomes that 1) are personally beneficial, 2) benefit others, and 3) avoid infringing upon the rights of others (Hosmer, 1995). In its long-term perspective, ESI recognizes that the pursuit of short-term goals may not actually be optimal and may result in the loss of a greater opportunity or benefit. ESI complies with the wisdom of moral intelligence that creates short-term value and long-term value while doing no harm (Lennick \& Kiel, 2011).

Throughout his life, Jesus Christ sought to serve others and to benefit their lives. His miracles and sermons were focused on enabling and empowering others. He explained, "I am come that they might have life, and that they might have it more abundantly" (John 10:10). At the same time, he affirmed his own divinity, declaring, "I am the resurrection and the life. He that believeth in me, though he were dead, yet shall he live. And whosoever liveth and believeth in me shall never die" (John 11: 25-26). Although he rebuked hypocrisy and dishonesty (Matt. 23: 1-4), Christ avoiding hurting others and his criticism was intended to encourage beneficial repentance.

\section{Virtue Ethics}

Virtue Ethics (VE) encompasses actions and choices that are flourishing, that represent the best of the human condition, and that enhance quality of life (Cameron, 2011). VE has its roots in the work of Aristotle who observed that a thoughtful, reasoned life is the life most worth living. Aristotle argued for moderation as the foundation for virtues (Aristotle \& Bartlett, 2012). According to Aristotle, character was about behavior and kindness involved creating the proper inner state or feelings about others. VE has an amplifying effect that enhances performance as well as a buffering effect that offsets negative consequences, dysfunction, and disappointment (Cameron, 2011).

Christ was both an exemplar of VE and an advocate of virtuous principles. Perhaps there is no greater example of his efforts to enrich human conduct than the Sermon on the Mount (Matt. 5 to 7). In that sermon, Christ not only raised the bar of expectations about the treatment of those whom a person loved but extended the requirement of virtuousness to those who were one's enemies (Matt. 5: 38-48). "Love your enemies," he declared (Matt: 5: 44). The quest, Christ counseled, was to overcome personal weakness, and develop virtue-summarized in his charge, "Be ye therefore perfect, even as your Father in Heaven is perfect"(Matt. 5:48).

\section{Ethic of Religious Injunction}

The Ethic of Religious Injunction (ERI) incorporates 1) the humanistic idea that each individual is important (Caldwell \& Anderson, 2017), 2) the obligation to treat others with kindness and compassion (Hosmer, 1995), and 3) the responsibility to establish relationships in harmony with the principles of charity and love (Trine, 2006). It 
advocates that persons should never take actions that are unkind or that are harmful to society or one's community (Hosmer, 1995). ERI is an ethical perspective based upon the assumption that people are "Yous" rather than "Its (cf. Buber \& Smith, 2011), and that they are inherently worthy of respectful treatment (Trine, 2006).

Christ's life reflected his love for everyone. At a time when class distinctions and condescension towards others typified societal relationships, Christ's parables positively exemplified the behaviors of those deemed to be of lower class (Luke 10: 25-37), dined with publicans and sinners (Mark 2: 13-17), and espoused a gospel wherein all men could return to a loving Father in Heaven (Luke 15: 11-32). Christ also taught so wisely that Jewish scholars marveled at his knowledge of the law (Matt. 12: 3-7; Matt 22: 29-32) and taught as one having authority about the scriptures (Luke 24: 27).

\section{Ethic of Government Requirements}

The Ethic of Government Requirements (EGR) acknowledges the obligations of the letter of the law but is equally concerned with honoring its spirit and intent (Hosmer, 1995). Obeying the law has often been considered a minimal standard of personal conduct, established by society to establish acceptable norms for a just society, to create order, and to preserve the common good (Simmons, 2008). Although EGR is an imperfect ethical standard, it establishes rules that govern social order and stability.

Christ was a respecter of the law and acknowledged its importance, but also emphasized that governmental requirements were superseded by the higher laws of God. In Matthew 22:15-21 Christ responded to the Herodians, a Hellenistic Jewish sect related to Herod the Great. Attempting to entrap Jesus, they queried, "Is it lawful to pay taxes to Caesar or not?" Christ perceived their intent, asked them to bring to him the money to pay such taxes, and queried, "Whose image and inscription is this?" When the men acknowledged that it was Caesar's, Christ responded, "Render unto Caesar the things that are Caesars, and to God the things that are Gods." In making his response, Jesus acknowledged the obligation to both honor the laws of man but, more importantly, to honor the laws of a loving God.

\section{Utilitarian Ethics}

Utilitarian Ethics (UE) emphasizes the consequences of one's actions with the intention of optimally benefiting others while limiting harm caused (Hosmer, 1995). John Stuart Mill (2012), one of the founders of Utilitarianism, defined positive outcomes and benefits as congruent with a Christian philosophy if one determines that the best possible consequence is consistent with the will of God. Other advocates of UE argued that the standard for assessing a consequence is the relative measure of benefits vs. harms and is contextually determined (Caldwell \& Anderson, 2017). To most UE proponents, the ethic is measured by the relative benefits, utils, or pleasure generated versus the amount of negative consequences or pain resulting from available choices.

Jesus Christ centered his teachings on one's relationship with God and one's fellowmen. He taught that the commitment to love God and to love one's neighbors as oneself were the essence of the law and the teachings of the prophets (Matt. 22: 37-40). From a biblical perspective, that which is "good" is consistent with the purposes of God (cf. Genesis 1 \& 2) and, on that basis, Christ encouraged his disciples to "(s)eek ye first the kingdom of God and his righteousness" (Matt. 6:33) as life's most important priority. For Christ and his followers, utility or benefit is measured from an eternal perspective and requires that individuals learn from life's experiences.

\section{Ethic of Universal Rules}

The Ethic of Universal Rules (EUR) is based upon the assumption that there are correct principles which universally apply and which benefit everyone (cf. Lewis \& Norris, 2015). Immanuel Kant suggested that human nature was conflicted by both rationality and emotion and that rules were necessary to guide human action. Other scholars agreed that right and wrong were often subject to individual interpretation and therefore required the establishment of universal standards (Hauser, 2006). Other experts have suggested that leaders similarly owe a set of universal moral duties to other, based upon a set of principle-centered rules and values (Covey, 2004).

Perhaps the most universal principle of ethical behavior and the one most frequently cited by individuals about Christ's teachings is the Golden Rule. Christ told his disciples that "whatsoever ye would that me do to you, do ye even so to them" (Matt 7:27) and "(D)o to others as you would have them do to you" (Luke 6:32). His message was that the standards expected of Christian followers encompassed compliance with norms of human conduct that both 1) treated others as the children of God and brothers and sisters in a universal human family, and 2) as individuals with divine worth and potential (John 10:34-35). Loving God and loving others as oneself were the essence of divine law (Matt. 22: 37-39). 


\section{Ethic of Individual Rights}

The Ethic of Individual Rights (EIR) declares that 1) rights are inherently a moral concept; and 2) individuals have the right to enjoy security and self-interest, free from the control of government (Hosmer, 1995). Those fundamental rights protect freedom of speech, freedom of religion, the right of assembly, the right to privacy, and the right to own property free from the threat of improper seizure (Caldwell \& Anderson, 2017). The rights owed to individuals must be honored and should not be superseded by a public benefit (Hosmer, 1995).

Although the Jewish society in which Jesus lived was elitist in its classification of individuals by gender, race, occupation, religion, perceived piety, and wealth, Christ saw deeper into people's hearts and associated with people based upon their needs, the desires of their hearts, and their willingness to repent. He counseled others to "Judge not lest ye be not judged" (Matt 7: 1-3) -- inviting people of all backgrounds to repent and to treat others with charity and love. He treated the Samaritan woman at the well with dignity and respect, and declared his divine calling to her (John 4: 1 - 28). His mission was to uplift and to honor the innate value in others, rather than to simply condemn and judge them. To a woman taken in adultery, Christ told those who sought to kill her, "He who is without sin among you, let him first cast a stone" (John 8: 7). When those who had condemned the woman quietly exited, Jesus counseled the woman, "Neither do I condemn thee. Go, and sin no more" (John 8:8).

\section{Ethic of Economic Efficiency}

Hosmer (1995, p. 397) affirmed that "(b)asic rights are meaningless without the essentials of food, clothing, and shelter." The Ethic of Economic Efficiency (EEE) advocates the efficient use of resources and the elimination of waste. Using resources efficiently and being accountable for their proper utilization not only benefits society but is also a virtuous goal that imposes on individuals the obligation to be responsible and productive in their lives (Hosmer, 1995). EEE imposes on individuals the obligation to be wise stewards of their resources and abilities.

Jesus also taught his followers to be accountable with their resources and their talents. Perhaps Christ's clearest advocacy of the EEE is found in his parable of the talents (Matt. 25-14-30). Jesus explained that the kingdom of heaven could be compared to a man with servants who possessed talents in varying amounts. Each individual servant was expected to develop and magnify those talents efficiently and be accountable for their use. In the parable, those who developed their talents and created added value were praised but those who did not enhance their gifts and resources failed in their obligation to be profitable servants.

\section{Ethic of Distributive Justice}

The Ethic of Distributive Justice (EDJ) identifies the moral responsibility to serve the needs of those who may be poor, uneducated, unemployed or otherwise in need in the distribution of goods and services (Rawls, 1999). According to Rawls (1993, Lect. VIII), the needs of others should be determined according to three assumptions: 1) each person is to have as much liberty as possible, 2) each person is to be granted the same liberties, and 3) society's rules and principles must avail to everyone the opportunity to have access to social and economic advantage.

In his dealings with others, Christ exemplified generosity and kindness in all of his relationships. He cared about the welfare of others, was concerned about the poor, and the sick and needy. He spent his life doing good and demonstrated by his every action his interest in helping people to fulfill life's highest purposes. He counseled others to forgive others and to treat other people kindly, rather than to judge them. In the Sermon on the Mount he counseled to share one's possessions with those in need and to do good to all men - rather than only to one's friends and associates (Matt 5-7).

\section{Ethic of Contributing Liberty}

The underlying assumption of the Ethic of Contributing Liberty (ECL) is that the right to grow and to improve benefits both the individual and society (Nozick, 1974). Thus, any action must preserve the right of self-development and self-fulfillment for others. Nozick (1974) argued that the rights of the individual should not be sacrificed for a societal benefit and that each individual was important and should be given the opportunity to become their best.

In the parable of the laborers who came to work at different times throughout the day, Christ made the point that God's love and the opportunity for salvation was available to everyone (Matt. 20). Jesus' message clearly was that each individual was important and that they all could be blessed -- regardless of the time of life in which they began God's work. Throughout his ministry, Christ emphasized that the truth was available to empower each individual to receive God's choicest blessings by accepting God's truth and continuing in faith (John 8: 31-32). 


\section{Ethic of Self-Actualization}

The Ethic of Self-Actualization (ESA) incorporates the teleological or outcome-focused obligation to fulfill one's highest innate potential (Brady, 1999). ESA includes the responsibility "to determine what one's self is to become and then strive to achieve that" (Brady, 1999, p. 314). Aydin (1982, p. 129) suggested that ESA encompassed the ability to "act according to the will of God" in achieving one's highest capacities. Maslow (1993) explained that self-actualization was the moral fulfillment of one's individual calling, achieved by listening to one's inner voice. Carl Rogers (1995) described self-actualization as reaching the highest expression of oneself.

The life of Jesus Christ not only demonstrated his commitment to doing his Father's will but his desire that his

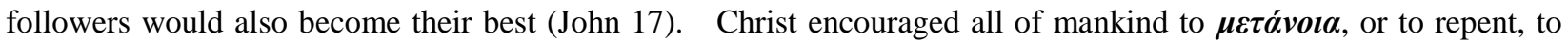
change their hearts and minds, and to change the inner man (Strong, 2010). Christ honored his earthly mission and fulfilled the work of his calling, exemplifying the highest standards of self-actualization (John 17:4). His counsel to his closest disciples was that they were to continue his work, to serve mankind, and to feed his sheep (John 21:17).

\section{Ethic of Care}

The Ethic of Care $(\mathrm{EoC})$ is a normative ethic, focused on honoring relationships and treating people compassionately with a commitment to their welfare (Gilligan, 1987; Noddings, 2002). It acknowledges interdependence with others and the duty to 1) promote the best interests of each person, and 2) protect their vulnerabilities (Slote, 2007). EoC focuses on personal responsibility to others and their personal best interests, as opposed to emphasizing rules of law and/or justice (Gilligan, 1982; Caldwell \& Anderson, 2017).

Christ's personal concern for others and his willingness to accept responsibility for their best interests was manifest throughout his life. Fairchild (2017) reported that the New Testament records thirty-seven miracles, all of which occurred to serve others and affirm Christ's unique role and "limitless compassion." In honoring his responsibility to mankind, Christ willingly accepted his mission to suffer for the sins of the world and give people the opportunity to fulfill their potential, serve God and their fellow men, and grow in maturity and love (Matt. 16:21; John 17: 2-3; John 3:16).

By honoring all twelve of the ethical perspectives of TE, Christ demonstrated his love for people, his commitment to their welfare and growth, and his desire that they achieve life's true purposes. Christ also honored his obligation to His Father in Heaven and exemplified the conduct he espoused. As a model of interpersonal and ethical propriety, Christ exemplified TE and its importance in earning the trust of his disciples and followers. Although the standards of TE do not demand human perfection, they call for a life of integrity and congruence that enables leaders and others who seek to be trusted to be perceived as honorable and trustworthy - thereby earning the commitment, followership, and respect of others (Hayes, Caldwell, Licona, \& Meyers, 2015).

\section{Four Insights}

In reflecting on the value of $\mathrm{TE}$ as a model for effective living, there are four practical insights that this paper suggests.

1) Leading is a profoundly personal ethical and moral relationship. Leaders earn trust by having integrity, honoring their word, and keeping their commitments. But ethical obligations often entail subjectively held perceptions about duties owed (Rousseau, 1995). Those subjective perceptions inevitably reflect the ethical perspectives of each person with whom leaders interact.

2) Leaders earn trust by their ethical deeds and actions. Trustworthiness is measured by a leader's behaviors - i.e., how the leader is perceived as demonstrating capacity, character, competence, and caring (Caldwell \& Ndalamba, 2017). Each of those behaviors is composed of an ethically-based component. If a leader's behaviors do not match an individual's expectations about ethical conduct, that leader is not perceived by that individual to be trustworthy (Caldwell \& Hayes, 2007)!

3) Followers choose leaders who demonstrate acts of love. Love is perceived as behaviors demonstrating commitment to the long-term welfare, growth, and wholeness of others (Peck, 2003). Ethical leaders sustain others by that same love (Kouzes \& Posner, 1992) and that commitment of love reflects authentic and genuine caring which creates a powerful bond and lasting followership (cf. Atwijuka \& Caldwell, 2017).

4) Ethical leaders raise the bar ... for themselves and for others. Leaders who are universally perceived as ethical honor a broad range of ethical obligations with a corresponding set of duties encompassed in TE 
(Caldwell \& Anderson, 2017). By honoring the highest standards of ethical leadership, individuals raise the bar for themselves and model that same higher standard for others (Lee, Choi, Youn, \& Chun, 2017).

\section{Limitations}

The ethical standards and fundamental obligations of TE require both an intellectual understanding of all twelve ethical perspectives from which it is derived and the desire to be perceived as a highly ethical individual. Although many leaders wished to be trusted and followed, they often overlook ethical duties implicit in their relationships with others (Caldwell, 2012). For Christians who seek to emulate the life of Christ, this paper encourages those individuals to rethink their ethical duty -- but the challenges of day-to-day life and the imperfections of would-be adherents place limits on the ability to fully comply with the standards of TE.

\section{Recommendations for Further Research}

There are numerous opportunities for the practical application of this paper and the principles and fundamentals which make up TE.

1) We encourage scholars, religious leaders, and practitioners to engage in practical discussions about TE and its application in others' lives.

2) A scale for measuring all twelve of the ethical perspectives of TE, including a self-assessment instrument for individuals, could be developed and utilized as a metric for identifying individuals' ethical perspectives and for suggesting opportunities for personal improvement. Empirical studies could also be undertaken to identify how TE is applied by other highly respected leaders.

3) A self-assessment instrument could be used to identify the areas where leaders commonly fail to incorporate TE in their lives and additional papers could address the ethical significance of those shortcomings in creating high trust organizational cultures (cf. Caldwell \& Floyd, 2014).

\section{Conclusion}

Although moral conduct and the ability to act ethically are not dependent upon one's religious beliefs (Hauser, 2007), the life of Christ is nonetheless an ideal standard for those who seek to increase the quality of relationships with others and their effectiveness as leaders (cf. Caldwell \& Jeane, 2007). Stephen R. Covey, a committed follower of Christ and a religious scholar-- as well as a world-class management consultant -- defined the ethical obligation of a leader to others in his definition of leadership. Covey (2004, p. 98) wrote, "Leadership is treating people so well that they come to recognize their greatness and strive to achieve it."

Marianne Williamson (1996, pp. 190-191) wrote the inspiring words, "You are a child of God. Your playing small does not serve the world ... We are all meant to shine, as children do. We were born to make manifest the glory of God that is within us. It's not just in some of us; it's in everyone. And as we let our own light shine, we unconsciously give other people permission to do the same. As we are liberated from our own fear, our presence automatically liberates others." TE enables its adherents to not only shine but to help others to shine as well.

In his discussion of moral leadership, Pellicer (2008) observed that caring leadership is not about what one does but who one becomes. Great leaders earn trust my giving of themselves - manifestations of that which is alive in him or her that enriches others. By honoring the standards and duties of TE, those who seek to raise the bar of their relationships and performance can enrich themselves and those whom they seek to serve.

\section{References}

Aristotle \& Bartlett, R. C. (2012). Aristotle's Nichomachean Ethics. Chicago, IL: University of Chicago Press.

Atwijuka, S., \& Caldwell, C. (2017). Authentic Leadership and the Ethic of Care. Journal of Management Development, 36(8), 1076-1086.

Aydin, M. (1982). The Ethics of Self-Realization with a Special Reference to Al-Farabi. Journal of the Faculty of Divinity of Ankara University, 25(1), 129-138.

Badaracco, J. L. Jr. (2016). Managing in the Gray: Five Timeless Questions for Resolving Your Toughest Problems at Work. Boston, MA: Harvard Business Review Press.

Baker, A. (2017). What is Ethical Stewardship? Career Trend July 5, found online on September 20, 2017 at https://careertrend.com/info-8429452-ethical-stewardship.html.

Brady, F. N. (1999). A Systematic Approach for Teaching Ethics in Business. Journal of Business Ethics, 19, 309-318. https://doi.org/10.1023/A:1005904915906 
Buber, M. \& Smith, R.G. (2011). I and Thou. New York: Amazon Digital Press.

Caldwell, C. (2012). Moral Leadership: A Transformative Model for Tomorrow's Leaders. New York: Business Expert Press.

Caldwell, C., Anderson, V. Caldwell, C., \& Anderson, V. (2017). Transformative Ethics: An Integrative Model of Ethical Stewardship. Paper presented at the International Academy of Management and Business Conference in New Orleans, Louisiana on January 20, 2017.

Caldwell, C., \& Floyd, L. A. (2014). High Performance Work Systems: Building Commitment to Increase Profitability. Graziadio Business Review, 17(3), found online at http://gbr.pepperdine.edu/2014/12/high-performance-work-systems/.

Caldwell, C., Hasan, Z., \& Smith, S. (2015). Virtuous Leadership: Insights for the $21^{\text {st }}$ Century. Journal of Management Development, 34(9), 1181-1200. https://doi.org/10.1108/JMD-11-2014-0148

Caldwell, C., \& Hayes, L. (2007). Leadership, Trustworthiness, and the Mediating Lens. Journal of Management Development, 26(3), 261-278. https://doi.org/10.1108/02621710710732155

Caldwell, C., Hayes, L., Karri, R., \& Bernal, P. (2008). Ethical Stewardship: The Role of Leadership Behavior and Perceived Trustworthiness. Journal of Business Ethics, 78(1/2), 153-164. https://doi.org/10.1007/s10551-006-9320-1

Caldwell, C., \& Anderson, V. (2017). Transformative Ethics: An Integrative Model of Ethical Stewardship. Paper presented at the International Academy of Management and Business Conference in New Orleans, Louisiana on January 20, 2017.

Cameron, K. (2011). Responsible Leadership as Virtuous Leadership. Journal of Business Ethics, 98, 25-35. https://doi.org/10.1007/s10551-011-1023-6

Covey, S. R. (2004). The $8^{\text {th }}$ Habit: From Effectiveness to Greatness. New York: Free Press.

Fairchild, M. (2017). Miracles of Jesus: 37 New Testament Miracles of Christ in Chronological Order. ThoughtCo. July 7, 2017 found online on September 20, 2017.

Gilligan, C. (1987). "Moral Orientation and Moral Development" in Women and Moral Theory. Lanham, MD: Rowman \& Littlefield. E. F. Kittay and D. T Meyers (Eds.) pp. 19-23.

Hauser, M. D. (2006). Moral Minds: The Nature of Right and Wrong. New York: Harper Collins.

Hayes, L. A., Caldwell, C., Licona, B., \& Meyer, T. E. (2015). Followership Behaviors and Barriers to Wealth Creation. Journal of Management Development, 34(3), 270-285. https://doi.org/10.1108/JMD-09-2013-0111

Hosmer, L. T. (2010). The Ethics of Management ( $7^{\text {th }}$ ed.). New York: McGraw Hill.

Hosmer, L. T. (1995). Trust: The Connecting Link between Organizational Theory and Philosophical Ethics. Academy of Management Review, 20(2), 379-403.

Kouzes, J. M., \& Posner, B. Z. (1992). Ethical Leaders: An Essay About Being in Love. Journal of Business Ethics, 11(5/6), 479-484. https://doi.org/10.1007/BF00870559

Lee, D., Choi, Y., Youn, S., \& Chun, J. (2017). Ethical Leadership and Employee Moral Voice: The Mediating Role of Moral Efficacy and the Moderating Role of Leader-Follower Value Congruence. Journal of Business Ethics, 141(1), 47-57. https://doi.org/10.1007/s10551-015-2689-y

Lennick, D. \& Kiel, F. (2011). Moral Intelligence 2.0: Enhancing Business Performance and Leadership Success in Turbulent Times. Boston, MA: Pearson Education.

Lewis, C. S. \& Norris, K. (2015). Mere Christianity. New York: HarperCollins.

Maslow, A. (1993). The Farther Reaches of Human Nature. New York: Penguin Books.

Mill, J. S. (2012). Utilitarianism. Metairie, LA: Renaissance Classics.

Noddings, N. (2002). Educating Moral People. New York: Teachers College Press.

Peck, M. S. (2003). A Road Less Traveled Timeless Edition. A New Psychology of Love, Traditional Values, and Spiritual Growth. New York: Touchstone.

Rawls, J. (1999). A Theory of Justice. New York: Belknap Press.

Rawls, J. (1993). Lectures on the History of Moral Philosophy. Boston, MA: Harvard University Press. 
Rogers, C. R. (1995). On Becoming a Person: A Therapist's View of Psychotherapy. New York: Houghton Mifflin.

Rousseau, D. M. (1995). Psychological Contracts in Organizations: Understanding Written and Unwritten Agreements. Thousand Oaks, CA: Sage Publishing.

Schwartz, M. (2016). Ethical Decision-Making Theory: An Integrated Approach. Journal of Business Ethics, 139(4), 755-776. https://doi.org/10.1007/s10551-015-2886-8

Simmons, N. (2008). Law as a Moral Idea. Oxford, UK: Oxford University Press. https://doi.org/10.1093/acprof:oso/9780199552191.001.0001

Strong, J. (2010). The New Strong's Expanded Exhaustive Concordance of the Bible. Nashville, TN: Thomas Nelson Publishers.

Trine, R. W. (2006). The Universal Religion and the Basic Principle of All Religions - Pamphlet. Whitefish, MT: Kessinger Publishing.

Ware, J. (2010). The Challenge of Ethical Leadership. CFA Magazine, 21(4), 10-13. https://doi.org/10.2469/cfm.v21.n4.2

Williamson, M. (1996). A Return to Love: Reflections on the Principles of a Course in Miracles. New York: Harper Collins. 